\title{
Induksi Mutasi Kalus Embriogenik Gandum (Triticum aestivum L.) melalui Iradiasi Sinar Gamma untuk Toleransi Suhu Tinggi
}

\section{Mutation Induction on Embryogenic Callus of Wheat (Triticum aestivum L.) through Gamma Ray Irradiation for High Temperature Tolerance}

\author{
Ryan Budi Setiawan ${ }^{1}$, Nurul Khumaida ${ }^{2 *}$, dan Diny Dinarti ${ }^{2}$ \\ 'Program Studi Pemuliaan dan Bioteknologi Tanaman, Sekolah Pascasarjana, Institut Pertanian Bogor \\ ${ }^{2}$ Departemen Agronomi dan Hortikultura, Fakultas Pertanian, Institut Pertanian Bogor \\ (Bogor Agricultural University), Jl. Meranti, Kampus IPB, Darmaga, Bogor 16680, Indonesia
}

Diterima14 Juni 2014/Disetujui 29 Oktober 2014

\begin{abstract}
Mutation techniques through gamma ray irradiation is useful to support breeding programs for genetic improvement of wheat. Genetic improvement on tolerance to high temperatures is necessary for development of wheat in Indonesia. The purpose of this study was to determine the level of radiosensitivity to be used as the basis for the induction of mutations by gamma ray irradiation on embryogenic callus to obtain putative mutants with high temperature tolerance. Explants used were embryogenic callus cultured on MS medium containing $30 \mathrm{~g} \mathrm{~L}^{-1}$ sukrosa, $2 \mathrm{~g} \mathrm{~L}^{-1}$ gelrite, $2 \mathrm{mg} \mathrm{L}^{-1} 2.4 \mathrm{D}$ and $1 \mathrm{mg} \mathrm{L}^{-1}$ picloram. Culture incubated for 6 weeks with temperature $20 \pm 4^{\circ} \mathrm{C}$ in the room culture. Five irradiation doses $(10,20,30,40$ and $50 \mathrm{~Gy}$ ) were used in radiosensitivity testing. A factorial, completely randomized design was applied to the experiment. The first factor was selection temperature with three levels $\left(25,30\right.$ and $\left.35^{\circ} \mathrm{C}\right)$, and the second factor was doses of gamma ray iradiation with three levels $(10,20$, and $30 \mathrm{~Gy}$ ). The result showed that radiosensitivity levels varied among varieties, $L D_{20}: 7.79$ to $18.96 \mathrm{~Gy}$ and $L D_{50}: 24.29-33.63 \mathrm{~Gy}$. Selayar variety which has highest sensitivity value compared with Dewata and Nias. Increasing doses of iradiation and temperature decrease survival of embryogenic callus, number of embryos, and percentage of germinated plantlets. Based on in vitro selection using high temperature $\left(25,30\right.$, and $\left.35^{\circ} \mathrm{C}\right)$, the obtained 19 putative mutants were derived from embryos that appear on the surface of embryogenic callus survival after irradiation and high temperature selection.
\end{abstract}

Keywords: in vitro selection, putative mutant, radiosensitivity, somatic embryo

\section{ABSTRAK}

Teknik mutasi melalui iradiasi sinar gamma dapat digunakan untuk menunjang program pemuliaan tanaman dalam rangka perbaikan genetik tanaman gandum. Perbaikan genetik seperti toleransi terhadap suhu tinggi perlu dilakukan untuk pengembangan gandum di Indonesia. Tujuan penelitian ini adalah menentukan nilai radiosensitivitas yang akan digunakan sebagai dasar induksi mutasi melalui iradiasi sinar gamma pada kalus embriogenik untuk memperoleh mutan putatif yang memiliki toleransi terhadap suhu tinggi. Eksplan yang digunakan adalah kalus embriogenik yang dikulturkan pada media MS yang mengandung $30 \mathrm{~g} \mathrm{~L}^{-1}$ sukrosa, $2 \mathrm{~g} \mathrm{~L}^{-1}$ gelrite, $2 \mathrm{mg} \mathrm{L}^{-1} 2.4 \mathrm{D}$ dan $1 \mathrm{mg} \mathrm{L}^{-1}$ picloram. Kultur diinkubasi di ruang kultur selama 6 minggu pada suhu $20 \pm 4^{\circ} \mathrm{C}$. Pengujian radiosensitivitas menggunakan lima dosis iradiasi $(10,20,30,40$ dan 50 Gy). Nilai radiosensitivitas yang diperoleh bervariasi antara setiap varietas, $L D_{20}: 7.79$ to $18.96 G y$ dan $L D_{50}: 24.29-33.63$ Gy. Rancangan yang digunakan untuk seleksi suhu tinggi adalah rancangan acak lengkap faktorial. Faktor pertama adalah suhu seleksi yang terdiri dari tiga taraf $\left(25,30\right.$ dan $\left.35^{\circ} \mathrm{C}\right)$ dan faktor kedua adalah dosis iradiasi sinar gamma yang terdiri atas tiga taraf $(10,20$ dan 30 Gy). Kultur diinkubasi sesuai suhu seleksi yang digunakan selama 4 minggu. Selayar merupakan varietas yang memiliki nilai sensitivitas paling tinggi dibandingkan Dewata dan Nias. Meningkatnya dosis iradiasi dan suhu menurunkan daya hidup kalus embriogenik, jumlah embrio, dan persentase planlet yang berkecambah. Berdasarkan seleksi in vitro menggunakan suhu tinggi $\left(25,30\right.$, dan $\left.35^{\circ} \mathrm{C}\right)$ diperoleh 19 mutan putatifyang berasal dari embrio yang muncul pada permukaan kalus embriogenik yang bertahan hidup setelah dilakukan iradiasi dan seleksi suhu tinggi.

Kata kunci: embrio somatik, mutan putatif, radiosensitivitas, seleksi in vitro

\footnotetext{
* Penulis untuk korespondensi. e-mail: nkhumaida@yahoo.com
} 


\section{PENDAHULUAN}

Gandum (Triticum aestivum L.) merupakan salah satu tanaman pangan utama yang ditanam hampir di seluruh dunia. Luas penanaman gandum mencakup sekitar 30\% area penanaman sereal di dunia, dengan lebih dari 220 juta ha areal budidaya (Cossani dan Reynolds, 2012). Kebutuhan gandum di Indonesia sangat tinggi, hal ini ditunjukkan oleh tingginya impor pada tahun 2012 mencapai 6,300,000 ton (BPS, 2013) setara dengan nilai US\$ 298,516,200 (Kemenperin, 2013). Berbagai persoalan dihadapi dalam pengembangan gandum di Indonesia di antaranya, terbatasnya varietas yang beradaptasi terhadap lingkungan tropis. Di daerah asalnya gandum dibudidayakan pada suhu $8-10{ }^{\circ} \mathrm{C}$ dan menghendaki suhu $10-21{ }^{\circ} \mathrm{C}$ sebagai suhu optimal untuk pertumbuhan (Fischer dan Maurer, 1978), persaingan lahan penanaman gandum di dataran tinggi dengan tanaman hortikultura, selain itu terjadinya perubahan iklim global yang sangat berpengaruh pada berbagai aspek pertanian dan lingkungan seperti peningkatan polusi udara, meningkatnya tingkat radiasi UV, perubahan curah hujan, ketidakteraturan musim, kehilangan air dan pemanasan global yang menyebabkan peningkatan suhu juga menghambat pengembangan gandum di Indonesia. Peningkatkan suhu sekitar 1.8 sampai $5.8^{\circ} \mathrm{C}$ diprediksi akan terjadi diakhir abad ini (IPCC, 2007).

Berbagai upaya pemuliaan harus dilakukan untuk meningkatkan toleransi tanaman gandum terhadap cekaman lingkungan abiotik seperti peningkatan suhu melalui perbaikan genetik. Eksploitasi keragaman genetik melalui induksi mutasi adalah salah satu cara yang dibutuhkan pada program pemuliaan tanaman dalam mengembangkan varietas tanaman yang memiliki keunggulan karakter tertentu. Tujuan dari induksi mutasi adalah untuk meningkatkan laju frekuensi mutasi sehingga diperoleh varian dengan tingkat keragaman yang tinggi yang akan diseleksi sesuai dengan karakter yang diinginkan. Induksi mutasi dapat dilakukan dengan menggunakan mutagen kimia dan fisik. Iradiasi sinar gamma merupakan salah satu jenis mutagen fisik yang biasa digunakan untuk meningkatkan keragaman genetik pada berbagai tanaman. Perlakuan mutagen akan merusak DNA dan selama proses perbaikan DNA akan terjadi mutasi baru yang diinduksi secara acak. Perubahan dapat terjadi pada organel di sitoplasma maupun mutasi kromosom inti (Jain, 2010).

Tingkat sensitivitas terhadap radiasi dapat diukur berdasarkan nilai $\mathrm{LD}_{50}$ (lethal dose 50) yaitu dosis yang menyebabkan kematian $50 \%$ dari populasi tanaman yang diradiasi. Beberapa penelitian menunjukkan bahwa dosis optimum yang dapat menghasilkan mutan terbanyak umumnya diperoleh di sekitar $\mathrm{LD}_{50}$ (Shu et al., 2012). Nilai $\mathrm{LD}_{50}$ sangat dipengaruhi oleh jenis tanaman, varietas, kandungan air dan oksigen. Penelitian yang dilakukan oleh Puchooa (2005) mengenai iradiasi sinar gamma pada kalus tanaman Anthurium menyatakan $\mathrm{LD}_{50}$ diperoleh pada dosis iradiasi 15 Gy. Ling et al. (2008) menyatakan LD $_{50}$ pada kalus jeruk sekitar 27 Gy sedangkan hasil penelitian Mahadevamma et al. (2012) menunjukkan pada kalus pepaya sekitar $30 \mathrm{~Gy}$.
Induksi mutasi mampu menghasilkan mutan dengan tingkat keragaman pada banyak karakter yang bisa diseleksi, sementara dengan pendekatan transgenik hanya satu karakter yang bisa diintegrasikan kedalam genom tanaman. Pendekatan transgenik juga memiliki kekurangan dalam hal regulasi dan penerimaan tanaman hasil rekayasa genetika. Keuntungan spesifik dari mutasi induksi adalah untuk mengembangkan galur mutan yang kemudian diidentifikasi karakter gen spesifiknya dalam rangka membangun database gen, untuk studi molekular yang berkaitan dengan fungsi genomik, pengembangan bioinformatika dan untuk pengembangan varietas yang dapat tumbuh pada lahan pertanian di bawah kondisi perubahan iklim (Jain, 2010).

Iradiasi sinar gamma telah banyak digunakan pada berbagai tanaman dalam rangka peningkatan keragaman genetik untuk toleransi cekaman abiotik dan biotik serta peningkatan kuantitas dan kualitas hasil, diantaranya: tomat (Ishfaq et al., 2012), wortel (Nagananda et al., 2013), kentang (Ahmad et al., 2010), kedelai (Alify et al., 2013), padi (Shanthi et al., 2010), sorghum (Soeranto dan Sihono, 2010), dan gandum (Singh dan Balyan, 2009; Borzouei et al., 2010; Plamenov et al., 2013). Tujuan penelitian ini adalah mendapatkan nilai radiosensitivitas sebagai dasar untuk melakukan induksi mutasi menggunakan iradiasi sinar gamma untuk memperoleh mutan putatif gandum yang memiliki toleransi terhadap suhu tinggi.

\section{BAHAN DAN METODE}

Penelitian ini dilaksanakan di Laboratorium Kultur Jaringan 3 Departemen Agronomi dan Hortikultura Fakultas Pertanian, Institut Pertanian Bogor mulai bulan November 2013 sampai dengan Juli 2014. Iradiasi sinar gamma dilakukan di Pusat Aplikasi Tenaga Isotop dan Radiasi Badan Tenaga Nuklir Nasional (PATIR BATAN). Eksplan yang digunakan adalah kalus embriogenik dari tiga varietas gandum yaitu Dewata, Selayar dan Nias.

\section{Penentuan Nilai Radiosensitivitas Iradiasi Sinar Gamma Kalus Embriogenik Gandum Varietas Dewata, Nias dan Selayar}

Percobaan ini disusun berdasarkan rancangan acak lengkap dengan perlakuan dosis iradiasi sinar gamma yang terdiri dari lima taraf yaitu: 10, 20, 30, 40 dan 50 Gy. Setiap perlakuan diulang sebanyak 5 kali sehingga diperoleh 25 satuan percobaan dan setiap satuan percobaan dikulturkan 4 clump kalus embriogenik dengan ukuran $1 \mathrm{~cm} \times 1 \mathrm{~cm}$ pada media MS dengan penambahan $30 \mathrm{~g} \mathrm{~L}^{-1}$ sukrosa, $2 \mathrm{~g}$ $\mathrm{L}^{-1}$ gelrite, $2 \mathrm{mg} \mathrm{L}^{-1} 2.4 \mathrm{D}$ dan $1 \mathrm{mg} \mathrm{L}^{-1}$ picloram. Kultur dipelihara di ruang kultur selama 6 minggu pada suhu $20 \pm 4{ }^{\circ} \mathrm{C}$. Pengamatan yang dilakukan meliputi: penambahan diameter dan bobot kalus embriogenik serta nilai radiosensitivitas $\left(\mathrm{LD}_{20}\right.$ dan $\left.\mathrm{LD}_{50}\right)$. Nilai radiosensitivitas diperoleh berdasarkan kombinasi data skoring perubahan warna (data tidak disampaikan), penambahan diameter dan bobot kalus embriogenik yang mencerminkan persentase kalus yang bertahan hidup. 
Induksi Mutasi Sinar Gamma dan Seleksi In Vitro Kalus Embriogenik Gandum terhadap Cekaman Suhu Tinggi

Percobaan ini disusun berdasarkan rancangan acak lengkap faktorial. Faktor pertama yaitu suhu seleksi yang terdiri dari tiga taraf $\left(25,30\right.$, dan $\left.35^{\circ} \mathrm{C}\right)$. Faktor ke dua adalah dosis iradiasi diantara $\mathrm{LD}_{20}$ dan $\mathrm{LD}_{50}$ yang terdiri atas tiga taraf (10, 20, dan 30 Gy). Setiap kombinasi perlakuan diulang sebanyak $10 \mathrm{kali}$, sehingga diperoleh 90 satuan percobaan dan setiap satuan percobaan dikulturkan 5 clump kalus embriogenik dengan ukuran $1 \mathrm{~cm} \times 1 \mathrm{~cm}$ pada media MS dengan penambahan $30 \mathrm{~g} \mathrm{~L}^{-1}$ sukrosa, $2 \mathrm{~g} \mathrm{~L}^{-1}$ gelrite, $2 \mathrm{mg}$ $\mathrm{L}^{-1}$ 2.4D dan $1 \mathrm{mg} \mathrm{L}^{-1}$ picloram. Kultur dipelihara selama 4 minggu sampai dihasilkan embrio somatik. Perkecambahan embrio somatik menggunakan media MS (MS tanpa ZPT) dan dipelihara selama 4 minggu hingga terbentuk planlet. Pengamatan yang dilakukan meliputi: penambahan bobot dan diameter kalus embriogenik, persentase dan jumlah kalus embriogenik yang bertahan hidup, jumlah embrio somatik, serta persentase perkecambahan planlet normal.

\section{Analisis Data}

Data penambahan bobot dan diameter kalus embriogenikdianalisis secara statistikmenggunakan program SAS 9.1, sedangkan penentuan nilai radiosensitivitasnya menggunakan program Curve expert 32. Nilai rata-rata dihitung dan dibandingkan menggunakan uji selang berganda duncan $(\mathrm{DMRT})$ pada taraf $5 \%(\mathrm{p}<0.05)$

\section{HASIL DAN PEMBAHASAN}

Penentuan Nilai Radiosensitivitas Iradiasi Sinar Gamma Kalus Embriogenik Gandum Varietas Dewata, Nias dan Selayar

Salah satu cara yang dapat digunakan untuk mengetahui tingkat radiosensitivitas suatu tanaman terhadap iradiasi sinar gamma adalah dengan mengetahui Lethal Doses $\left(\mathrm{LD}_{20}\right.$ dan $\mathrm{LD}_{50}$ ) dari tanaman tersebut (Rakotoarisoa et al., 2008). Perubahan warna, penambahan bobot dan diameter kalus dapat digunakan untuk menduga nilai radiosensitivitas pada kalus embriogenik gandum. Penambahan diameter dan bobot kalus embriogenik mengalami penurunan seiring meningkatnya dosis iradiasi pada semua varietas yang digunakan (Tabel 1). Iradiasi dosis tinggi diduga menyebabkan kerusakan pada organel-organel di dalam sel. Kerusakan tersebut mempengaruhi fungsi fisiologis dan biokimia dalam metabolisme sel sehingga terhambatnya pertumbuhan dan perkembangan sel.

Kalus yang tumbuh dan bertahan hidup umumnya berwarna putih kekuningan, sedangkan kalus yang berwarna kecokelatan hingga menghitam selnya diduga mengalami kematian. Iradiasi gamma dosis rendah mampu memicu pertumbuhan dan menstimulasi perubahan fisiologis tanaman, sedangkan pada dosis yang tinggi akan menghasilkan radikal bebas dalam bentuk hidroksil. Radikal hidroksil/ hidrogen peroksida akan menyebabkan kerusakan fisiologis berupa terhambatnya proses pembelahan dan diferensiasi sel dan kerusakan gen jika radikal hidroksil tersebut menempel pada rantai nukleotida yang menyebabkan rusaknya DNA (Suharsono et al., 2009).

Nilai $\mathrm{LD}_{20}$ dan $\mathrm{LD}_{50}$ yang diperoleh bervariasi antar varietas gandum (Tabel 2). Varietas Selayar menunjukkan tingkat sensitivitas iradiasi sinar gamma yang lebih tinggi dengan nilai radiosensitivitas berkisar antara 7.79-24.29 Gy. Hal ini mengindikasikan bahwa sel pada varietas Selayar lebih mudah mengalami kerusakan akibat iradiasi dibandingkan kedua varietas lain yang memerlukan iradiasi lebih tinggi untuk mendapatkan nilai $\mathrm{LD}_{20}$ dan $\mathrm{LD}_{50}$. Faktor fisik, biologi dan fisiologi mempengaruhi sensitivitas tanaman, di antaranya: faktor genotipe, tanaman yang memiliki jumlah kromosom lebih banyak mempunyai sensivitas lebih tinggi dibanding tanaman yang memiliki jumlah kromosom yang lebih sedikit, fase perkembangan sel, saat fase pembelahan akan lebih peka dibanding pada fase istirahat (resting), dan umur jaringan. Nilai radiosensitivitas tanaman juga berkaitan erat dengan kandungan air di dalam sel tanaman (Herison et al., 2008).

\section{Induksi Mutasi Sinar Gamma dan Seleksi In Vitro Kalus Embriogenik Gandum terhadap Cekaman Suhu Tinggi}

Seleksi in vitro toleransi terhadap cekaman suhu tinggi pada kalus embriogenik yang telah diradiasi sinar gamma dilakukan pada inkubator yang suhunya diatur pada suhu 25,30 dan $35^{\circ} \mathrm{C}$. Hasil analisis ragam menunjukkan bahwa iradiasi sinar gamma dan perlakuan suhu seleksi

Tabel 1. Penambahan diameter dan bobot kalus embriogenik gandum selama 6 minggu pada uji radiosensitivitas

\begin{tabular}{lcccccc}
\hline \multirow{2}{*}{$\begin{array}{l}\text { Iradiasi } \\
\text { Gy })\end{array}$} & \multicolumn{3}{c}{ Penambahan diameter $(\mathrm{mm})$} & \multicolumn{3}{c}{ Penambahan bobot $(\mathrm{mg})$} \\
\cline { 2 - 7 } & Dewata & Nias & Selayar & Dewata & Nias & Selayar \\
\hline 10 & $3.18 \mathrm{a}$ & $2.71 \mathrm{a}$ & 2.51 & $226.40 \mathrm{a}$ & $297.60 \mathrm{a}$ & $234.58 \mathrm{a}$ \\
20 & $2.86 \mathrm{~b}$ & $2.55 \mathrm{ab}$ & 2.42 & $201.80 \mathrm{a}$ & $172.64 \mathrm{~b}$ & $201.48 \mathrm{a}$ \\
30 & $2.86 \mathrm{~b}$ & $2.53 \mathrm{ab}$ & 2.37 & $148.80 \mathrm{ab}$ & $128.00 \mathrm{~b}$ & $135.64 \mathrm{ab}$ \\
40 & $2.82 \mathrm{~b}$ & $2.30 \mathrm{~b}$ & 2.40 & $60.80 \mathrm{c}$ & $82.30 \mathrm{~b}$ & $94.12 \mathrm{~b}$ \\
50 & $2.39 \mathrm{c}$ & $2.45 \mathrm{ab}$ & 2.28 & $76.20 \mathrm{bc}$ & $64.20 \mathrm{~b}$ & $79.70 \mathrm{~b}$ \\
\hline
\end{tabular}

Keterangan: Angka yang diikuti huruf kecil yang sama pada kolom yang sama menunjukkan tidak berbeda nyata berdasarkan uji DMRT $\operatorname{taraf} 5 \%$ 
Tabel 2. Nilai radiosensitivitas $\left(\mathrm{LD}_{20}\right.$ dan $\left.\mathrm{LD}_{50}\right)$ pada kalus embriogenik gandum

\begin{tabular}{llccc}
\hline Varietas & Tipe Grafik & Persamaan & $\mathrm{LD}_{20}(\mathrm{~Gy})$ & $\mathrm{LD}_{50}(\mathrm{~Gy})$ \\
\hline Dewata & Polynomial fit & $\mathrm{y}=\mathrm{a}+\mathrm{bx}+\mathrm{cx}^{2}+\mathrm{dx}^{3}$ & 18.96 & 33.63 \\
Nias & Polynomial fit & $\mathrm{y}=\mathrm{a}+\mathrm{bx}+\mathrm{cx}^{2}+\mathrm{dx}^{3}$ & 13.52 & 33.05 \\
Selayar & Exponential fit & $\mathrm{y}=\mathrm{ae}^{(\mathrm{bx})}$ & 7.79 & 24.29 \\
\hline
\end{tabular}

Keterangan: Nilai radiosensitivitas menggunakan iradiasi sinar gamma pada energi $638.7409 \mathrm{Ci}$

secara tunggal memberikan pengaruh yang nyata terhadap penambahan diameter kalus embriogenik selama empat minggu inkubasi pada semua varietas. Rata-rata penambahan diameter menurun seiring dengan peningkatan dosis iradiasi, yaitu pada varietas Dewata berkisar 1.01-1.76 $\mathrm{mm}$, pada varietas Nias berkisar 0.73-1.34 mm, sedangkan pada varietas Selayar berkisar 0.46-1.17 mm. Perlakuan suhu tinggi yang semakin meningkat juga menurunkan rata-rata penambahan diameter, yaitu pada varietas Dewata berkisar 1.08-1.67 mm, pada varietas Nias berkisar 0.62$1.42 \mathrm{~mm}$, sedangkan pada varietas Selayar berkisar 0.60$1.12 \mathrm{~mm}$ (Tabel 3). Data menunjukkan bahwa rata-rata penambahan diameter varietas Dewata cenderung lebih tinggi dibandingkan dengan kedua varietas lain pada semua perlakuan iradiasi dan suhu seleksi, hal ini diduga varietas Dewata memiliki tingkat toleransi cekaman suhu tinggi lebih baik dibandingkan varietas lain, atau diduga pada sel-sel kalus embriogenik yang telah diradiasi pada varietas Dewata telah mampu menginduksi gen dan aktifnya mekanisme ketahanan terhadap cekaman suhu tinggi. Perlakuan suhu memberikan pengaruh yang nyata terhadap rata-rata penambahan bobot kalus embriogenik pada semua varietas. Penambahan bobot akibat iradiasi menurun seiring meningkatnya dosis iradiasi, yaitu pada varietas Dewata berkisar 103.4-137.4 mg, pada varietas Nias berkisar 117.09-140.51 mg, sedangkan pada varietas Selayar berkisar 54.13-125.91 mg. Perlakuan suhu yang semakin meningkat juga menurunkan rata-rata penambahan bobot kalus embriogenik, yaitu pada varietas Dewata berkisar 78.67-177.20 mg, pada varietas Nias berkisar 86.69-212.01 mg sedangkan pada varietas Selayar berkisar 59.01-146.80 mg (Tabel 4).

Peningkatan dosis iradiasi dan suhu menyebabkan perubahan warna dan penghambatan pertumbuhan kalus embriogenik. Kondisi tersebut menunjukkan terjadinya kematian sel-sel di sekitarnya melalui programmed cell death (PCD). Menurut van Doorn et al. (2011), PCD merupakan bagian integral dari perkembangan tanaman selama morfogenesis jaringan, organ, atau embrio yang disebabkan oleh rusaknya vakuola atau sebagai respon terhadap stres biotik dan abiotik yang menyebabkan terjadinya nekrosis.

Tabel 3. Penambahan diameter ( $\mathrm{mm}$ ) kalus embriogenik gandum selama 4 minggu setelah iradiasi sinar gamma dan seleksi in vitro pada suhu $25^{\circ} \mathrm{C}, 30^{\circ} \mathrm{C}$, dan $35^{\circ} \mathrm{C}$

\begin{tabular}{|c|c|c|c|c|}
\hline \multirow{2}{*}{ Iradiasi (Gray) } & \multicolumn{3}{|c|}{ Penambahan diameter (mm) } & \multirow{2}{*}{ Rata-rata $(\mathrm{mm})$} \\
\hline & $25^{\circ} \mathrm{C}$ & $30^{\circ} \mathrm{C}$ & $35^{\circ} \mathrm{C}$ & \\
\hline \multicolumn{5}{|l|}{ Dewata } \\
\hline 10 & 2.05 & 1.60 & 1.62 & $1.76 \mathrm{a}$ \\
\hline 20 & 1.64 & 1.03 & 0.88 & $1.18 \mathrm{~b}$ \\
\hline 30 & 1.32 & 0.98 & 0.74 & $1.01 \mathrm{~b}$ \\
\hline Rata-rata & $1.67 \mathrm{~A}$ & $1.20 \mathrm{AB}$ & $1.08 \mathrm{~B}$ & \\
\hline \multicolumn{5}{|l|}{ Nias } \\
\hline 10 & 1.65 & 1.43 & 0.93 & $1.34 \mathrm{a}$ \\
\hline 20 & 1.51 & 1.37 & 0.57 & $1.15 \mathrm{a}$ \\
\hline 30 & 1.10 & 0.75 & 0.35 & $0.73 b$ \\
\hline Rata-rata & $1.42 \mathrm{~A}$ & $1.18 \mathrm{~A}$ & $0.62 \mathrm{~B}$ & \\
\hline \multicolumn{5}{|l|}{ Selayar } \\
\hline 10 & 1.45 & 1.20 & 0.85 & $1.17 \mathrm{a}$ \\
\hline 20 & 1.28 & 1.39 & 0.64 & $1.10 \mathrm{a}$ \\
\hline 30 & 0.62 & 0.47 & 0.30 & $0.46 \mathrm{~b}$ \\
\hline Rata-rata & $1.12 \mathrm{~A}$ & $1.02 \mathrm{~A}$ & $0.60 \mathrm{~B}$ & \\
\hline
\end{tabular}

Keterangan: Angka yang diikuti huruf kecil yang sama pada kolom yang sama dan huruf besar yang sama pada baris yang sama menunjukkan tidak berbeda nyata berdasarkan uji DMRT taraf 5\%. Varietas bukan sebagai faktor perlakuan 
Tabel 4. Penambahan bobot (mg) kalus embriogenik gandum selama 4 minggu setelah iradiasi sinar gamma dan seleksi in vitro pada suhu $25^{\circ} \mathrm{C}, 30^{\circ} \mathrm{C}$, dan $35^{\circ} \mathrm{C}$

\begin{tabular}{|c|c|c|c|c|}
\hline \multirow{2}{*}{ Iradiasi (Gy) } & \multicolumn{3}{|c|}{ Penambahan bobot (mg) } & \multirow{2}{*}{ Rata-rata (mg) } \\
\hline & $25^{\circ} \mathrm{C}$ & $30^{\circ} \mathrm{C}$ & $35^{\circ} \mathrm{C}$ & \\
\hline \multicolumn{5}{|l|}{ Dewata } \\
\hline 10 & 209.81 & 109.60 & 92.80 & 137.40 \\
\hline 20 & 167.42 & 90.00 & 72.03 & 109.81 \\
\hline 30 & 154.40 & 84.60 & 71.20 & 103.40 \\
\hline Rata-rata & $177.21 \mathrm{~A}$ & $94.73 \mathrm{~B}$ & 78.67B & \\
\hline \multicolumn{5}{|l|}{ Nias } \\
\hline 10 & 222.52 & 113.48 & 85.52 & 140.51 \\
\hline 20 & 218.14 & 80.88 & 95.62 & 131.55 \\
\hline 30 & 195.36 & 76.96 & 78.94 & 117.09 \\
\hline Rata-rata & $212.01 \mathrm{~A}$ & $90.44 \mathrm{~B}$ & $86.69 \mathrm{~B}$ & \\
\hline \multicolumn{5}{|l|}{ Selayar } \\
\hline 10 & 230.38 & 77.94 & 69.4 & $125.91 \mathrm{a}$ \\
\hline 20 & 152.24 & 72.92 & 54.86 & $93.34 \mathrm{ab}$ \\
\hline 30 & 57.78 & 51.82 & 52.78 & $54.13 b$ \\
\hline Rata-rata & $146.80 \mathrm{~A}$ & $67.56 \mathrm{~B}$ & $59.01 \mathrm{~B}$ & \\
\hline
\end{tabular}

Keterangan: Angka yang diikuti huruf kecil yang sama pada kolom yang sama dan huruf besar yang sama pada baris yang sama menunjukkan tidak berbeda nyata berdasarkan uji DMRT taraf 5\%. Varietas bukan sebagai faktor perlakuan.

Persentase daya hidup kalus embriogenik sangat rendah dengan meningkatnya dosis iradiasi dan suhu seleksi. Persentase daya hidup kalus embriogenik pada varietas Dewata berkisar 34.0-70.0\%, Nias berkisar 36.0-76.0\% dan Selayar berkisar 0.0-56.0\% (Tabel 5). Varietas Selayar menunjukkan daya hidup kalus embriogenik paling rendah, mengindikasikan bahwa tingkat sensitivitas varietas Selayar terhadap iradiasi dan suhu tinggi lebih besar dibandingkan varietas lainnya. Kalus embriogenik yang bertahan hidup dan berdiferensiasi pada kondisi suhu tinggi tersebut diduga sebagai kandidat mutan yang toleran terhadap cekaman suhu tinggi. Rostika et al. (2013) menyatakan bahwa iradiasi dosis rendah (1-5 krad) dan perlakuan suhu hingga $25^{\circ} \mathrm{C}$ dan $30^{\circ} \mathrm{C}$ pada kalus purwoceng mampu menstimulir

Tabel 5. Persentase (\%) kalus embriogenik yang bertahan hidup selama 4 minggu setelah iradiasi sinar gamma pada suhu $25{ }^{\circ} \mathrm{C}, 30{ }^{\circ} \mathrm{C}$, dan $35^{\circ} \mathrm{C}$

\begin{tabular}{|c|c|c|c|c|}
\hline \multirow{2}{*}{ Iradiasi (Gy) } & \multirow{2}{*}{$\begin{array}{c}\text { Jumlah kalus } \\
\text { ditanam }\end{array}$} & \multicolumn{3}{|c|}{ Persentase kalus } \\
\hline & & $25^{\circ} \mathrm{C}$ & $30^{\circ} \mathrm{C}$ & $35^{\circ} \mathrm{C}$ \\
\hline \multicolumn{5}{|l|}{ Dewata } \\
\hline 10 & 50 & $58(29)$ & $70(35)$ & $60(30)$ \\
\hline 20 & 50 & $54(27)$ & $38(19)$ & $36(18)$ \\
\hline 30 & 50 & $50(25)$ & $44(22)$ & $34(17)$ \\
\hline \multicolumn{5}{|l|}{ Nias } \\
\hline 10 & 25 & 76 (19) & $68(17)$ & $68(17)$ \\
\hline 20 & 25 & $72(18)$ & $76(19)$ & $60(15)$ \\
\hline 30 & 25 & $60(15)$ & $44(11)$ & $36(9)$ \\
\hline \multicolumn{5}{|l|}{ Selayar } \\
\hline 10 & 25 & $56(14)$ & $40(10)$ & $44(11)$ \\
\hline 20 & 25 & $36(9)$ & $28(7)$ & $12(3)$ \\
\hline 30 & 25 & $24(6)$ & $16(4)$ & $0(0)$ \\
\hline
\end{tabular}

Keterangan: Angka di dalam kurung merupakan jumlah total kalus hidup 
terbentuknya embrio somatik, tetapi hanya embrio somatik pada suhu $25^{\circ} \mathrm{C}$ yang mampu beregenerasi menjadi planlet. Planlet yang dihasilkan diduga sebagai mutan putatif yang toleran terhadap suhu tinggi.

Daya hidup sel pada kalus embriogenik juga diduga sangat dipengaruhi oleh kandungan antioksidan yang terbentuk saat iradiasi dan seleksi pada suhu tinggi pada setiap varietas. Antioksidan diperlukan dalam mekanisme detoksifikasi penanganan radikal bebas yang dihasilkan ketika terpapar iradiasi sinar gamma dan akibat tercekam suhu tinggi. Kandungan antioksidan yang berbeda pada setiap varietas mempengaruhi ketahanan terhadap radikal bebas yang dihasilkan seperti ROS (reactif oxigen species) dan hidrogen peroksida. Sistem pertahanan terhadap radikal bebas melibatkan sistem enzimatik maupun non enzimatik. Sistem antioksidan enzimatik seperti ascorbat peroksidase, dehidroaskorbat reduktase, glutatione S-transferase, superoxida dismutase, catalase, guaicol peroksidase, glutatione reduktase, sedangkan antioksidan non enzimatik seperti glutatione, ascorbat dan tokophenol. Sel yang memiliki kandungan antioksidan yang lebih tinggi biasanya akan lebih bisa bertahan saat kandungan radikal bebas di dalam sel meningkat (Wahid et al., 2007).

Kalus embriogenik yang bertahan hidup seharusnya mampu menghasilkan sejumlah embrio somatik yang dapat dikecambahkan menjadi planlet sebagai mutan putatif toleran suhu tinggi. Penelitian ini menunjukkan bahwa hanya kalus embriogenik darivarietas Dewata yang mampumenghasilkan embrio somatik dengan persentase perkecambahan planlet normal yang rendah berkisar $5.0 \%$ pada iradiasi 20 Gy dan suhu $30{ }^{\circ} \mathrm{C}$ hingga $24.24 \%$ pada iradiasi 10 Gy dan suhu $25{ }^{\circ} \mathrm{C}$ (Gambar 1). Rendahnya persentase perkecambahan embrio somatik membentuk planlet diduga akibat perlakuan iradiasi dan suhu menyebabkan terjadinya kerusakan organel di dalam sel embrio somatik yang berpengaruh terhadap aktifitas metabolisme. Hasil ini berbeda dengan yang dikemukakan oleh Rostika et al. (2013) yang menyatakan bahwa peningkatan dosis iradiasi hingga $5 \mathrm{Krad} / 50$ Gy mampu menstimulir munculnya embrio somatik lebih banyak dibandingkan dosis rendah, bahkan iradiasi dosis tinggi mampu memicu pendewasaan embrio somatik melalui penghambatan pertumbuhan proliferasi kalus. Hal ini diduga dosis iradiasi yang tinggi mampu mengubah rasio fitohormon auksin dan sitokinin sehingga mengubah pola diferensiasi sel.

Aplikasi iradiasi sinar gamma dosis rendah pada kalus embriogenik varietas Dewata yang dilanjutkan dengan seleksi in vitro ketahanan terhadap suhu tinggi mampu menghasilkan sejumlah planlet yang berkecambah, walaupun banyak embrio somatik yang berkecambah abnormal yang dapat dilihat dari banyaknya jumlah akar yang dihasilkan tetapi pertumbuhan tunas terhambat. Menurut Shu et al. (2012), perubahan fisiologis dan genetik dapat diekspresikan dengan adanya perubahan penampilan fenotipik mutan yang bervariasi. Umumnya ukuran mutan hasil induksi mutasi akan lebih pendek dengan ukuran daun kecil, bahkan ada tunas albino yang muncul. Pada generasi selanjutnya, kerusakan fisiologis berangsur pulih. Sel-sel yang mengalami kerusakan mengalami recovery, sedangkan gen termutasi dapat diwariskan pada generasi berikutnya.

Hasil perkecambahan embrio somatik hanya menghasilkan 19 planlet mutan putatif dari varietas Dewata (Tabel 6) yang memiliki morfologi normal dengan daun dan akar sempurna (Gambar 2). Beberapa planlet mengalami pemudaran warna daun dan terhambatnya pertumbuhan. Pemudaran warna daun tersebut diduga akibat terjadi kerusakan pada kloroplas sehingga berdampak pada produksi klorofil. Hal ini sejalan dengan hasil penelitian yang dilakukan oleh Hasbullah et al. (2012) yang menyatakan bahwa iradiasi sinar gamma dosis 40-60 Gy menyebabkan kerusakan pada kloroplas yang ditandai terjadinya nekrosis dan albino pada daun tanaman Gerbera jamesonii.

Planlet varietas Dewata yang dihasilkan pada percobaan ini diharapkan menjadi mutan putatif yang toleran dan adaptif terhadap suhu tinggi. Varian yang terjadi diharapkan bukan disebabkan oleh epigenetik melainkan
A

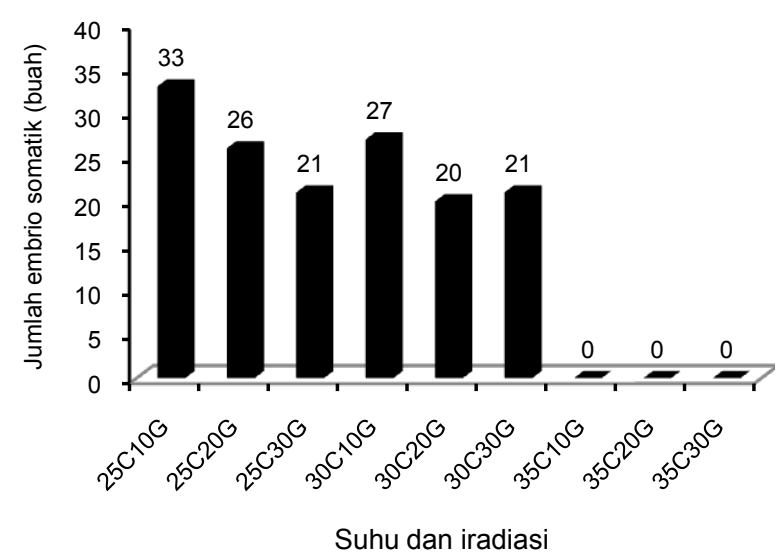

B

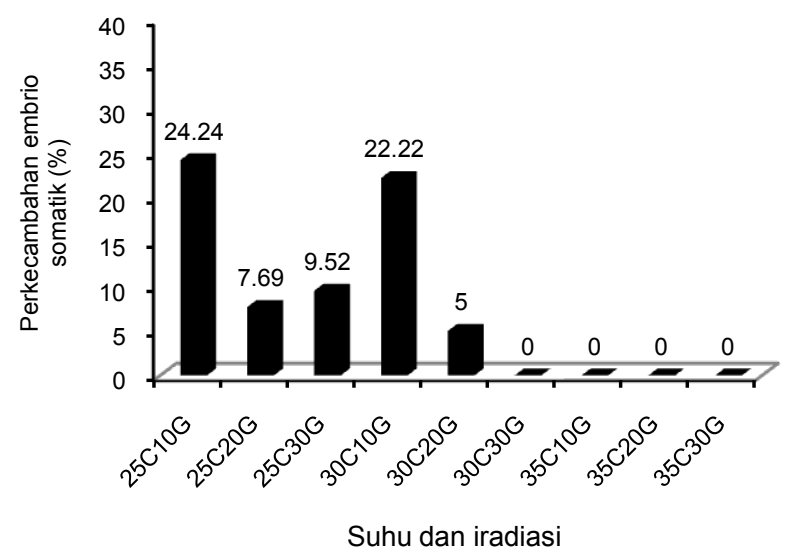

Gambar 1. Jumlah embrio somatik (A), persentase perkecambahan embrio somatik setelah iradiasi dan pengujian suhu tinggi varietas Dewata (B) 
J. Agron. Indonesia 43 (1) : 36 - 44 (2015)

Tabel 6. Karateristik mutan putatif toleran suhu tinggi pada varietas Dewata

\begin{tabular}{|c|c|c|c|}
\hline Kode mutan & Tinggi planlet $(\mathrm{cm})$ & Jumlah daun (helai) & Warna daun \\
\hline 10GY25C-1 & 20.3 & 6 & Hijau muda \\
\hline 10GY25C-2 & 16.5 & 5 & Hijau muda \\
\hline 10GY25C-3 & 17.0 & 5 & Hijau muda \\
\hline $10 \mathrm{GY} 25 \mathrm{C}-4$ & 17.5 & 6 & Hijau tua \\
\hline $10 G Y 25 C-4$ & 19.7 & 6 & Hijau tua \\
\hline 10GY25C-5 & 20.0 & 6 & Hijau muda \\
\hline 10GY25C-6 & 15.5 & 5 & Hijau tua \\
\hline 10GY25C-7 & 17.5 & 6 & Hijau muda \\
\hline 20GY25C-1 & 18.6 & 5 & Hijau muda \\
\hline 20GY25C-2 & 15.5 & 4 & Hijau muda \\
\hline 30GY25C-1 & 16.5 & 5 & Hijau keputihan \\
\hline 30GY25C-2 & 17.3 & 5 & Hijau keputihan \\
\hline 10GY30C-1 & 22.0 & 5 & Hijau keputihan \\
\hline 10GY30C-2 & 13.5 & 5 & Hijau keputihan \\
\hline 10GY30C-3 & 21.0 & 6 & Hijau tua \\
\hline 10GY30C-4 & 18.0 & 5 & Hijau tua \\
\hline 10GY30C-5 & 18.5 & 5 & Hijau muda \\
\hline 10GY30C-6 & 19.0 & 5 & Hijau muda \\
\hline 20GY30C-1 & 14.5 & 4 & Hijau keputihan \\
\hline
\end{tabular}

Keterangan: Kode mutan putatif mengikuti dosis iradiasi dan agen seleksi cekaman suhu tinggi

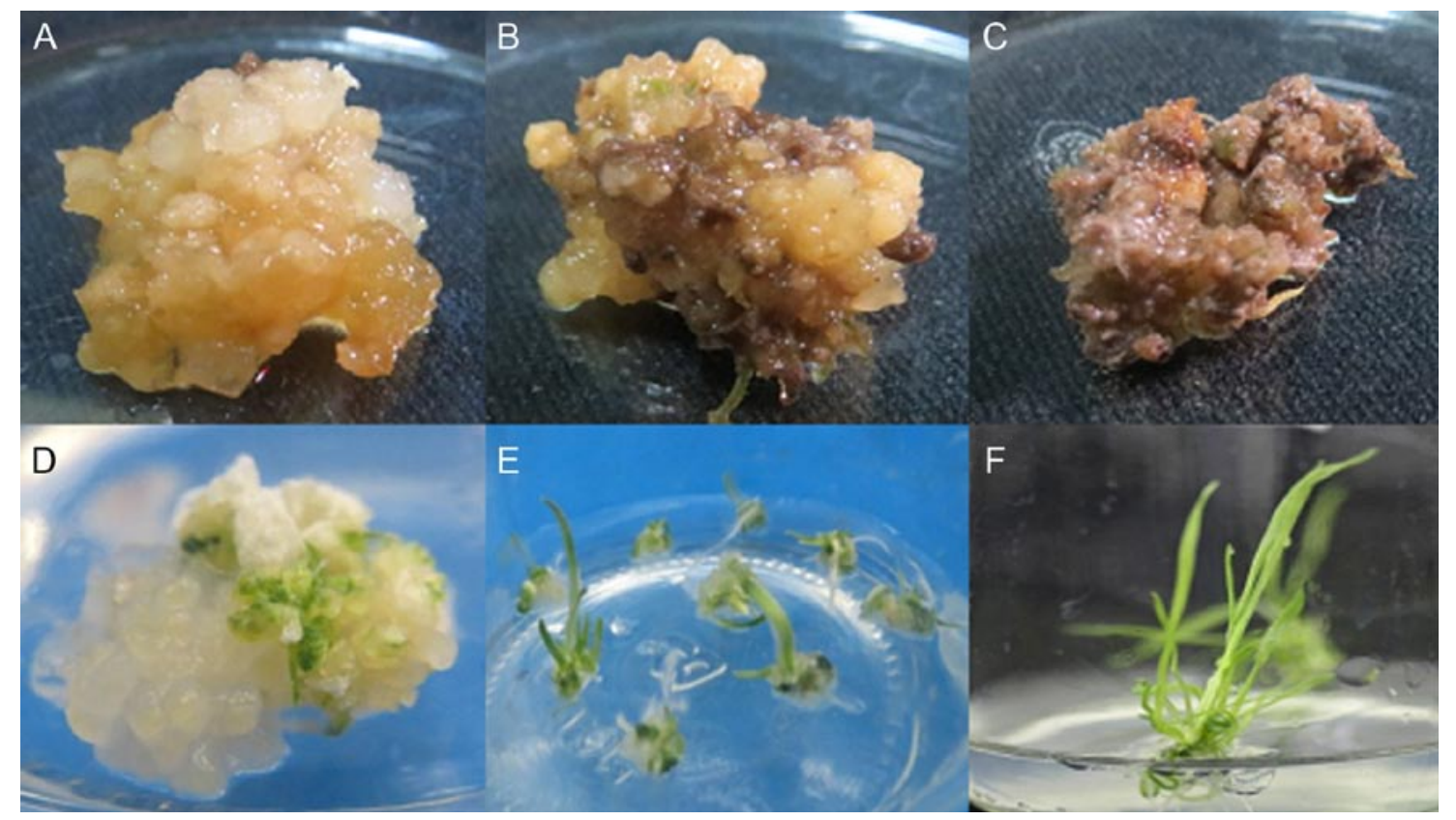

Gambar 2. Morfologi kalus dan perkecambahan. Suhu $25{ }^{\circ} \mathrm{C}(\mathrm{A}) ; 30{ }^{\circ} \mathrm{C}(\mathrm{B}) ; 35^{\circ} \mathrm{C}(\mathrm{C})$; kalus embriogenik yang menghasilkan embrio somatik (D); perkecambahan embrio somatik (E); planlet mutan putatif $(\mathrm{F})$

terbentuk sebagai hasil mutasi sehingga ketahanannya bersifat permanen dan dapat diwariskan. Menurut Plamenov et al. (2013) varian yang disebabkan oleh epigenetik tidak bersifat permanen dan tidak dapat diwariskan pada keturunan. Suhu tinggi pada seleksi in vitro tidak hanya berfungsi sebagai agen penyeleksi tetapi juga dapat menginduksi terjadinya mutasi selektif atau mutasi terarah sehingga dihasilkan varian yang diinginkan. 


\section{KESIMPULAN}

Nilai radiosensitivitas kalus embriogenik antar varietas gandum sangat bervariasi, $\mathrm{LD}_{20}: 7.79$ to $18.96 \mathrm{~Gy}$ dan $\mathrm{LD}_{50}$ : 24.29-33.63 Gy. Semakin tinggi dosis iradiasi sinar gamma menyebabkan diameter dan bobot kalus embriogenik semakin rendah, warna kalus menjadi kecoklatan hingga menghitam; hal ini diduga terjadi akibat adanya kerusakan sel pada kalus. Secara umum suhu tinggi dan iradiasi sinar gamma menurunkan daya hidup kalus, menghambat munculnya embrio somatik serta menurunkan daya berkecambah embrio somatik menjadi planlet. Percobaan yang dilakukan mampu menghasilkan 19 planlet mutan putatif dari varietas Dewata yang diduga memiliki toleransi terhadap suhu tinggi. Oleh karena itu perlu dilakukan penelitian lanjutan untuk aklimatisasi dan evaluasi planlet mutan putatif toleran suhu tinggi yang telah dihasilkan.

\section{TERIMA KASIH}

Terima kasih disampaikan kepada DIKTI atas Hibah Pascasarjana 2012-2014, biaya penelitian Beasiswa Unggulan DIKTI 2012-2014, Pusat Aplikasi Tenaga Isotop dan Radiasi, Badan Tenaga Nuklir Nasional (PATIR BATAN).

\section{DAFTAR PUSTAKA}

Ahmad, I., I.A. Nasir, M.S. Haider, M.A. Javed, M.A. Javed, Z. Latif, T. Husnain. 2010. In vitro induction of mutation in potato cultivar. Pak. J. Phytopathol. 22:51-57.

Alify, A.M.R., M.M. Rashed, A.M. Ebstam, H.S. Elbeltagi. 2013. Effect of gamma radiation on the lipid profiles soybean, peanut, dan sasame seed oils. Grasas. Y. Aceites. 64:256-368.

[BPS] Badan Pusat Statistik. 2013. Data impor gandum Indonesia 2012. http://www.bps.go.id [30 Juni 2014].

Borzouei, A., M. Kafi, H. Khazaei, B. Naseryan, A. Majdabadi. 2010. Effect of gamma radiation on germination and physiological of wheat (Triticum aestivum L.) seedlings. Pak. J. Bot. 42:2281-2290.

Cossani, C.M., M.P. Reynolds. 2012. Physiological traits for improving heat tolerance in wheat. Plant Physiol. 160:1710-1718.

Fischer, R.A., R. Maurer. 1978. Drought resistance in spring wheat cultivars, grain yield response. Aust. J. Agric. 29:897-912.

Hasbullah, N.A., R.M. Taha, A. Saleh, N. Mahmad. 2012. Irradiation effect on in vitro organogenesis, callus growth and plantlet development of Gerbera jamesonii. Horticultura Brasileira 30:252-257.

Herison, C., Rustikawati, H.S. Sujono, I.A. Syarifah. 2008. Induksi mutasi melalui sinar gamma terhadap benih untuk meningkatkan keragaman populasi dasar jagung (Zea mays L.). Akta Agrosia 11:57-62.

[IPCC] Intergovermental Panel on Climate Change. 2007. Intergovermental Panel on Climate Change Fourth Assesment Report Climate Change. Syntesis Report World Meteoralogical Organization. Geneva. Switzerland.

Ishfaq, M., I.A. Nasir, N. Mahmood, M. Saleem. 2012. In vitro induction of mutation in tomato (Lycopersicum esculentum L.) cv Roma by using chemical mutagen. Pak. J. Bot. 44:311-314.

Jain, M.S. 2010. Mutagenesis in crop improvement under the climate change. Rom. Biotechnol. Lett. 15:88106.

[Kemenperin] Kementrian Perindustrian Republik Indonesia. 2013. Pemantauan impor kelompok hasil industri makanan dan minuman. http://www. kemenperin.go.id [20 Maret 2013].

Ling, A.P.K., J.Y. Chia, S. Hussein, A.R. Harun. 2008. Physiological response of Citrus sinensis to gamma irradiation. World Appl. Sci. J. 5:12-19.

Mahadevamma, M., L. Sahijram, V. Kumari, T.H. Shankarappa. 2012. In vitro mutation studies in papaya (Carica papaya L.). J. Biotechnol. 1:49-55.

Nagananda, G.S., S. Rajath, D. Agarwal, K.R. Mathew, S.S. Rajan. 2013. Induced mutation in callus cell line of Daucus carota L. Asian J. Plant Sci. 12:46-50.

Plamenov, D., I. Beichev, N. Daskalova, D. Spetson, T. Moraliyski. 2013. Aplication of a low dose of gamma rays in wheat androgenesis. Arch. Biol. Sci. 65:291296.

Puchooa, D. 2005. In vitro mutation breeding of Anthurium by gamma radiation. Int. J. Agri. Biol. 7:11-20.

Rakotoarisoa, N.V., A. Andrianjaka, F.J. Zapataarias, R. Afza, C. Mba. 2008. Inducing cold tolerance in Malagasy rice varieties IR 58614, Malady and Rojofotsy through in vitro mutagenesis. Plant Mutat. Rep. 2:16-23.

Rostika, I., I. Darwati, Yudiwanti. 2013. Peningkatan keragaman genetik purwoceng melalui iradiasi sinar gamma dan seleksi in vitro. J. Littri 19:88-98. 
Shanthi, D., S. Jebaraj, S. Geetha. 2010. In vitro screening for salt tolerance in rice (Oryza sativa L.). Electronic J. of Plant Breeding 1:1208-1212.

Shu, Q.Y., B.P. Forster, H. Nakahawa. 2012. Plant Mutation Breeding and Biotechnology. CAB International and FAO. Wallingford. United Kingdom.

Singh, N.K., H.S. Balyan. 2009. Induced mutation in bread wheat (Triticum aestivum L.) cv. Kharchia 65 for reduced plant height and improved grain quality traits. Adv. Biol. Res. 3:215-221.

Soeranto, H., Sihono. 2010. Sorghum breeding for improved drought tolerance using induced mutation with gamma iradiation. J. Agron. Indonesia 38:95-99.
Suharsono, M. Alwi, A. Purwito. 2009. Pembentukan tanaman cabai haploid melalui induksi ginogenesis dengan menggunakan serbuk sari yang diradiasi sinar gamma. J. Agron. Indonesia 37:123-129.

van Doorn, W.G., E.P. Beers, J.L. Dangl, V.E. Franklintong, P. Gallois, I.H. Nishimura, A.M. Jones, K. Yamada, E.J. Lam, I.A.J. Mundy, M. Mur, A. Petersen, M. Smertenko, F. Taliansky, T. Van Breusegem, E. Wolpert, B. Woltering, Zhivotovsky, P.V. Bozhkov. 2011. Morphological classification of plant cell deaths. Cell Death and Differentiation 1:1-6.

Wahid, A., S. Gelani, M. Ashraf, M.R. Foolad. 2007. Heat tolerance in plants: an overview. Environ. Exp. Bot. 61:199-223. 